\title{
Larangan Ingkar Tanggung Jawab dalam QS. al-Ṣāffāt 139-148 Studi Hermeneutika Abdullah Saeed Atas Kisah Nabi Yūnus
}

\author{
Althaf Husein Muzakky \\ UIN Sunan Kalijaga Yogyakarta \\ e-mail: althafhusein@gmail.com
}

\begin{abstract}
Responsibility is a substantial thing. Almost at least a large part of welfare is determined by implementing responsibilities. This article explores the story of the Prophet Yünus in the Qur'an related to the Responsibility Statement. Through the Abdullah Saeed hermeneutics method this research aims to reveal the significance and value of the hierarchy in the story of the Prophet Yünus contained in the QS. al-Säffät verses 139-148. The results of this study reveal that in the story of the prophet Yünus has significance in the form of tasliyyah (entertainment) specifically for the prophet Muhammad's task and the da'wah of Islam in general. The significance of the story of the prophet Yünus has three urgencies namely Not running away from the responsibilities that have been mandated, not abusing authority, and being patient and polite in Da'wah Facing the people.
\end{abstract}

Keywords : Mindfulness of Responsibility, Prophet Jonah, Hermenutic, Abdullah Saeed.

\begin{abstract}
Abstrak
Tanggung jawab merupakan sebuah hal yang bersifat substansial. Hampir setidaknya sebagian besar kesejahteraan ditentukan dengan pelaksanaan tanggung Jawab. Tulisan ini mengupas tentang kisah Nabi Yünus dalam al-Qur'an kaitannya dengan Ingkar Tanggung Jawab. Melalui metode hermeneutika Abdullah Saeed penelitian ini bertujuan mengungkap signifikansi dan nilai hirarki dalam kisah Nabi Yünus yang terdapat dalam QS. al-Säffät ayat 139-148. Hasil penelitian ini mengungkapkan bahwa dalam kisah nabi Yünus memiliki signifikansi berupa tasliyyah (hiburan) secara khusus untuk nabi tugas Muhammad SAW dan dakwah Islam secara umum. Adapun signifikansi dari kisah nabi Yünus memiliki tiga urgensi yaitu Tidak lari dari tanggung jawab yang telah diamanahkan, tidak menyalahgunakan wewenang, dan Sabar dan santun dalam Berdakwah Menghadapi umat.
\end{abstract}

Kata kunci: Ingkar Tanggung Jawab, Nabi Yūnus, Hermenutika, Abdullah Saeed.

\section{Pendahuluan}

Tanggung jawab merupakan sebuah berkah sekaligus musibahbagi yang mendapatinya. Melalui tanggung jawab banyak hal dapat berubah terhadap dunia sosial masyarakat Indonesia secara khusus dan global. Tanggung jawab merupakan beban atau segala sesuatu yang diamanahkan kepada seseorang untuk mewujudkan maslahat, tentu jika dilakukan dengan benar dan tepat akan berdampat pada prestasi kebaikan umat, sebaliknya jika tidak sesuai maka hal tersebut dapatmenjadi bumerang sehingga boleh dituntut oleh masyarakat di saat di dunia maupun kelak di akirat sebagaimana ajaran agama Islam. Melaksanakan tanggung jawab adalah 
sebuah kewajiban, bukan sematamatadidasari bahwa melaksanakan tanggung jawab adalah ajaran agama, namun didalamnya juga terdapat kepercayaan sosial masyarakat yang harus diemban dengan tepat.

Walau demikian, ingkar tanggung jawab masih banyak dilakukan, dari hal tersebut setidaknya menyisakan tiga problem akademik. Pertama, peraturan tentang tanggung jawab telah jelas ditetapkan negara Indonesia dalam UU. No. 39 tahun 19991 begitu juga dalam alQur'an QS. al-Muddašsirir [74]: 38 akan tetapi banyak orang yang diberi tanggung jawab namun malah mengingkari². Kedua, Indonesia merupakan negara mayoritas Islam dengan tingkat korupsi 52 persen², dapat dilihat terdapat dua Menteri Agama Indonesia yang melakukan korupsi, sehingga jika dibuat rata-rata maka setidaknya dari seratus persen pejabat yang menduduki kursi jabatan setengah lebih diantaranya telah ingkar tanggung jawab dengan melakukan tindak korupsi padahal jelas tindakan yang ingkar

\footnotetext{
1“UU No.39 Thn 1999 - Hak Asasi Manusia (HAM)," dalam http://hukum.unsrat.ac.id/uu/uu_39_99.htm., diakses Tanggal 12 November 2019.

${ }^{2}$ Afrahul Fadhila Daulay, "Tanggung Jawab Pendidikan Islam,", jurnal al-Irsyad, Vol. 7, No. 2 (2017). Hlm. 70-80.

${ }^{3}$ Nurhadi Sucahyo, "Aneh, Masyarakat Religius Namun Korupsi Tinggi," Dalam Https:/ /Www.Voaindonesia.Com/A/Aneh-MasyarakatReligius-Namun-Korupsi-Tinggi/4587783.Html. diakses 12 November 2019.
}

tanggung jawab. Ketiga, kasus ingkar tanggung jawab banyak dilakukan oleh masyarakat religius, terdapat misunderstanding dan misintrepetation tentang ingkar tanggung jawab yang dianggap hanya dipertanggung jawabkan kelak diakhirat saja, padahal menurut penafsiran al-Qur'an tanggung jawab adalah sesuatu yang harus diselesaikan bahkan sejak saat di dunia.

Secara umum penelitian ini berangkat dari dua kecenderungan penulis atas kajian lieratur tentang larangan ingkar tanggung jawab.Pertama, Kajian ingkar terhadap tanggung jawab banyak dikaji lewat diskusi prespektif hukum ${ }^{4}$, padahal ingkar janji dapat terjadi disetiap hal, tidak hanya dalam wilayah hukum saja, tetapi dalam ranah yang lebih luas sebagai contoh dapat dilihat dalam tulisan wahyudi yang berjudul “Tanggung Jawab Rumah Sakit Terhadap Kerugian Akibat Kelalaian Tenaga Kesehatan Dan Implikasinya", kajian tentang ingkar tanggung jawab dapat masuk ke ranah yang lebih luas yaitu kesehatan, tidak menjamin bahwa tenaga kesehatan yang disumpah, namun tetap dapat ingkar terhadap tanggung jawab

\footnotetext{
4Triyanto Setyo Prabowo dan Mulyoto, “Tanggung Jawab Calon Notaris Yang Sedang Magang Terhadap Kerahasiaan Akta," Jurnal Repertorium Vol. 4, No. 2 (2 Juli 2017). Hlm. 71-79.
} 
yang diberikan ${ }^{5}$.Ingkar tanggung jawab juga didiskusikan dalam wilayah pendidikan,dapat dilihat penelitian dari Daulay yang berjudul "Tanggung Jawab Pendidikan Islam"6. Kedua ingkar tanggung jawab dikaji dengan telaah konsep bahasa dalam al-Qur'an seperti halnya tulisan Zaenuddin dan Hamdani yang berjudul "Formulasi Gaya Bahasa Ingkari dalam Alquran"7, dalam tulisan tersebut banyak mengeksplor linguistik alQur'an tentang penuturan ingkar. Dari kedua pemetaan yang telah disebutkan, studi tentang larangan ingkar masih bersifat parsial, oleh sebab itu penulis mengkaji larangan ingkar melalui kisah dalam al-Qur'an untuk mendapatkan pemahaman yang komprehensif.

Penelitian ini menawarkan gagasan baru dalam menyikapi bahaya ingkar terhadap tanggung jawab yang dilarang oleh agama dan negara. Dalam hal ini penulis mengajukan setidaknya dua rumusan masalah.Pertama, bagaiaman potert larangan ingkar tanggung jawab dalam QS. al-Ṣāffāt : 139148. Kedua, apa pesan yang dapat dipetik

5Setya Wahyudi, "Tanggung Jawab Rumah Sakit Terhadap Kerugian Akibat Kelalaian Tenaga Kesehatan Dan Implikasinya," Jurnal Dinamika Hukum, Vol. 11, No. 3, Hlm. 505-521.

${ }^{6}$ Daulay, "Tanggung Jawab Pendidikan Islam.", Jurnal al-Irsyad, Vol 7, No. 2, Hlm. 70-80.

${ }^{7}$ Mamat Zaenuddin Dan Wagino Hamid Hamdani, "Formulasi Gaya Bahasa Ingkari Dalam Alquran," Jurnal Pendidikan Bahasa Dan Sastra 15, No. 1. hlm, 1-12. dari kisah nabi Yūnus dalam QS. al-Ṣāffāt : 139-148. Kekurangan dari studi yang sudah ada, para peneliti banyak mengkaji kisah al-Qur'an dengan pemahaman tematis yang terkesan tekstualis, didalam penelitian terdahulu tidak disebutkan faktor internal dan faktor eksternal tentang sebab ingkar tanggung jawab, sehingga hanya memaparkan bahwa tanggung jawab adalah hal yang tidak boleh dilanggar tanpa memberikan solusi. Oleh sebab itu studi ini merupakan studi kualitatif dengan library reserachuntuk memperolehan datanya, melalui hermeneutika yang ditawarkan Abdullah Saeed, penulis hendak memaknai ulang kisah Nabi Yūnus dalam QS. al-Ṣāffāt : 139-148dengan hermeneutika atau tafsir kontekstual, Abdullah Saeed awalnya menyusun hermeneutika hanya untuk ayat ethico-legal (hukum), namun dalam penelitian ini Saeed akan digunakan untuk mengkaji ayat kisah, tentunya dengan mengintegrasi-interkoneksi pesan dan nilai dari pemahaman dimasa dulu dan tentunya dengan penyesuaian.

Artikel ini berangkat dari tiga asumsi dasar larangan ingkar tanggung jawab. Pertama, ingkar tanggung jawab akan berdampak pada demoralisasi yang terjadi dimasyarakat, tanggung jawab merupakan dasar dari adanya kepercayaan, dari hal itu, apabila 
tanggung jawab diingkari maka akan menyebabkan sikap kepedulian dimasyarakat menjadi berkurang, dan cenderung individualistik, maka jelas ingkar tanggung jawab adalah larangan keras. Selain itu ingkar tanggung jawab akan mengurangi rasa kepercayaan masyarakat terhadap pemerintah yang seharusnya melaksanakan tanggung jawab yang diamanahkan. Kedua, untuk menguatkan larangan ingkar tanggung jawab haruslah dengan diberikan semacam punishment yang dapat membuat jera, sehingga menjadi pelajaran bagi para pelaku supaya tidak lalai dan sembrono dalam mengemban sebuah amanah, seringnya tanggung jawab seperti jabatan disalah gunakan bukan untuk mewujudkan kemaslahatan, melainkan untuk meraup keuntungan. Ketiga, memberikan penghargaan setinggitingginya bagi seseorang yang berhasil menyelesaikan tanggung jawab dengan baik dan benar, hal ini berlaku bagi siapapun, entah itu pemerintah, kepala keluarga, dan seluruh bagian yang mengambil peran dalam mengemban tanggung jawab.

Studi Kisah Nabi Yūnus dan Telaah Metode Hermeneutika Abdullah Saeed

\section{Kisah Nabi Yūnus}

Kisah merupakan salah satu bagian isi al-Qur'an yang menuntun manusia menuju arah yang dikehendakiNya. Didalam al-Qur'an terdapat banyak sekali kisah, khususnya perjalanan rasul, nabi, dan utusan terdahulu beserta kaumnya sebelum terakhir yaitu Nabi Muhammad SAW. salah satu kisah yang menarik dibahas adalah kisah nabi Yūnus beserta umatnya. Didalam ulümul Qur'an terdapat kaidah apabila didalam al-Qur'an terdapat kisah yang tokohnya secara eksplisit jelas disebutkan secara tertentu, maka tokoh tersebut perlu diteladani, sebaliknya jika al-Qur'an menampilkan sisi kelemahan dan keburukannya, maka hal tersebut perlu dihindari, sebab didalam kisah alQur'an memiliki hakekat, makna, dan nilai pendidikan yang terkandung didalamnya ${ }^{8}$.Adapun kisah nabi Yūnus dalam al-Qur'an yaitu sebagai berikut:

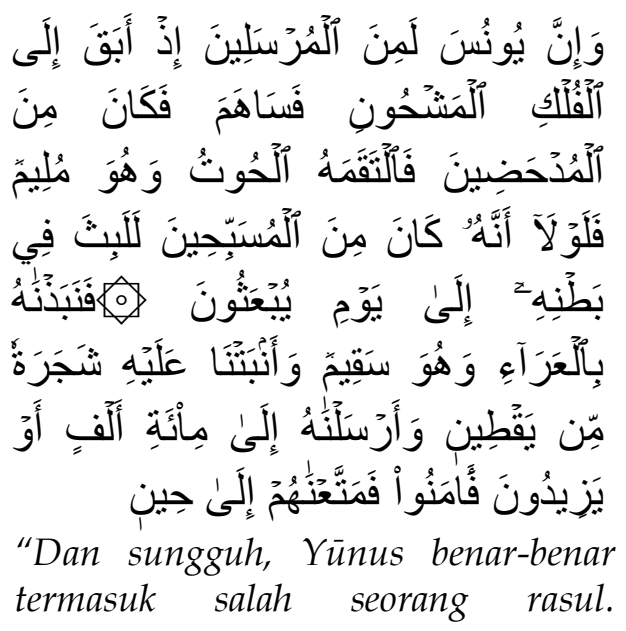

${ }^{8}$ Abdul Mustaqim, "Kisah Al-Qur'an: Hakekat, Makna, Dan Nilai-Nilai Pendidikannya," Ulumuna Vol. 15, No. 2 (2011): 265-290. 
(ingatlah) ketika dia lari, ke kapal yang penuh muatan. kemudian dia ikut diundi ternyata dia termasuk orangorang yang kalah (dalam undian). Maka dia ditelan oleh ikan besar dalam keadaan tercela. Maka sekiranya dia tidak termasuk orang yang banyak berzikir (bertasbih) kepada Allah. Niscaya dia akan tetap tinggal di perut (ikan itu) sampai hari kebangkitan. Kemudian Kami lemparkan dia ke daratan yang tandus, sedang dia dalam keadaan sakit. Kemudian untuk dia Kami tumbuhkan sebatang pohon dari jenis labu. Dan Kami utus dia kepada seratus ribu (orang) atau lebih. Sehingga mereka beriman, karena itu Kami anugerahkan kenikmatan hidup kepada mereka hingga waktu tertentu.(QS. al-Ṣāffāt [37]: 139-148).

Kisah nabi Yūnus telah dijelaskan Imam Jalāluddin al-Suyūti dalam tafsirnya. Pemilihan versi cerita dari Imam al-Suyūti, didasari bahwa kitab tersebut sangat populer dibanding tafsir yang lain menurut Martin 9. Nabi Yūnus merupakan nabi dari Bani Isrāil, nabi Yūnus merupakan putra Mata putra 'Ajūz merupakan keturunan dari Ya'qūb putra dari Isḥāq putra dari Ibrāhiīm. Nabi Yūnus dan nabi Ilyās merupakan nabi yang diutus dalam satu masa yang sama. Pada saat kecil nabi Yūnus pernah wafat, sampai kemudian didoakan oleh nabi Ilyās, dan lewat sebab doa nabi Ilyās tersebut kemudian nabi Yūnus hidup kembali, dan kemudian Allah mengutus

${ }^{9}$ Martin Van Bruinessen, Kitab Kuning, Pesantren, dan Tarekat (Yogyakarta: Gading Publishing, 2015). Hlm. 170 . nabi Yūnus untuk berdakwah di Nainawa (sekarang diwilayah Irak) yang notabene menyembah berhala. Nabi Yūnus diutus kepada kaum Nainawa untuk berdakwah supaya menyembah Allah ${ }^{10}$.

Kaum Nainawa hanya menerima ajaran dari keturunan mereka. Ketika Nabi Yūnus berdakwah, kaum Nainawa tidak sedikitpun menanggapi ajaran yang dibawa nabi Yūnus tersebut bahkan nabi Yūnus diancam ingin dibunuh. Hal ini kemudian menjadikan nabi Yūnus mengguggurkan dakwahnya, pada saat itu, nabi Yūnus memperingatkan kaum Nainawa untuk menyembah Allah dan bertaubat, pada saat sebelum pergi meninggalkan kaum Nainawa, nabi Yūnus marah dan berkata "wahai kaum Nainawa, apabila kalian semua tetap melakukan menyembah berhala, maka Allah akan menimpakan adzab yang sangat pedih, oleh sebab itu cepatlah bertaubat." Namun kaum Nainawa menyikapinya dengan menanti ucapan nabi Yūnus selama tiga hari, apabila dalam tiga hari tidak ada adzab maka nabi Yūnus akan segera dieksekusi. Mendengar hal itu nabi Yūnus pada hari kedua saat penantian adzab kemudian pergi meninggalkan kaum Nainawa yang

${ }^{10}$ Jalaluddin al-Mahalli dan Jalaluddin al-Suyuti, Tafsir Jalālain (Beirut: Dār al-Fikr al-Islāmy, 2017), Hlm. 426. 
sebenarnya merupakan dakwah dan perintah Allah yang tidak boleh ditinggalkan ${ }^{11}$.

Nabi Yūnus kemudian meninggalkan kaum Nainawa tanpa persetujuan Allah. Dalam masalah ini Imam Suyūti menjelaskan bahwa tindakanyang dilakukan nabi Yūnus ini merupakan hal biasa bagi jika nabi Yūnus merupakan manusia biasa, namun meninggalkan perintah yang dilakukan seorang nabi adalah sebuah kesalahan namun bukan berarti dosa. Setelah bersiap-siap nabi Yūnus kemudian menuju pelabuhan mengikuti rombongan kabilah yang naik kapal, namun ditengah perjalanan kapal tersebut bocor, dalam kepercayaan terdahulu apabila terdapat kapal yang tiba-tiba bocor, berarti terdapat penumpang gelap, orang yang kabur dari majikan, dan dalam hal ini nabi Yūnus diibaratkan orang yang lari dari utusan majikannya yaitu Allah SWT. kemudian dilakukan pengundian, dan ternyata benar, nabi Yūnus merupakan orang yang kalah dalam undian dan harus dilemparkan ke dalam laut. ${ }^{12}$

Pada saat nabi Yūnus dilemparkan kelaut maka terdapat ikan besar yang sihap melahap nabi Yūnus dalam keadaan

\footnotetext{
11 Jalaluddin al-Mahalli dan al-Suyuti, Tafsìr Jalālain, Hlm. 427.

12 Jalaluddin al-Mahalli dan al-Suyuti, Tafsir Jalālain, Hlm. 428.
}

utuh dan masih hidup didalam perut ikan tersebut. Dijelaskan dalam tafsir QS. alAnbiyā' [21]: 87 maka nabi Yūnus kemudian merasa bersalah dan bertaubat dengan membaca lāilā illā anta subhānaka innī kuntu min al-zälimìn. Bacaan tasbịh tersebut dibaca selama empat puluh hari berdzikir kemudian nabi Yūnus sampai kemudian dimuntahkan dari ikan tersebut, dalam versi lain nabi Yūnus ditelan dipagi hari dan dimuntahkan sore hari, Allah kemudian mengampuninya setelah membaca maka sekiranya dia tidak termasuk orang yang banyak berzikir (bertasbih) kepada Allah, maka Allah tidak akan mengeluarkannya. Setelah keluar dari perut ikan nabi Yūnusdalam keadaan lemas, kemudian datanglah seekor kijang yang menyusui nabi Yūnus, dan terdapat buah labu aneh yang menggelantung sehingga dapat dimakan nabi Yūnus sampai dapat pulih kembali. ${ }^{13}$

Disisi lain, kaum Nainawa hari ketika benar datang cuaca yang sangat buruk. Kaum Nainawa meyakini bahwa cuaca tersebut adalah pertanda dari datangnya adzab yang disabdakan nabi Yūnus. Setelah itu masyarakat Nainawa bertaubat mulai beriman kepada Allah, dan kemudian mulai mencari nabi Yūnus. Kaum Nainawa kemudian mulai mencari

\footnotetext{
13 Jalaluddin al-Mahalli dan al-Suyuti,Tafsir Jalālain, Hlm. 429.
} 
nabi Yūnus untuk memintanya berdakwah kembali, karena kebenaran kerasulannya, sampai saat kemudian kaum Nainawa bertemu Yūnus mereke kemudian menceritakan seluruh kejadian yang menimpa kaum Nainawa, sehingga mereka kemudian dianugerahi Allah dengan kenikmatan hidup sejahtera kepada mereka hingga waktu tertentu. ${ }^{14}$

\section{Metode Hermeneutika Abdullah Saeed}

Abdullah Saeed merupakan seorang pemikir Islam kontemporer yang menyempurnakan pemikiran double movement milik gurunya yaitu Fazlur Rahman 15. Dalam tulisannya yang berjudul "Interpreting the Qur'an: Towards a Contemporary Approach", banyak peneliti yang telah membahas pemikirannya yang mengkombinasikan antara tradisi pemahaman teks dengan analisis bahasa dan historis, nampaknya Abdullah Saeed juga menggali makna lain yang ada dalam setiap redaksi teks. Tulisan rahman banyak diterjemahkan dan dikaji sebagai wacana baru pemikiran Islam seperti buku pengantar studi alQur'an 16, metode tafsir kontekstualnya

14 Jalaluddin al-Mahalli dan al-Suyuti, Tafsir Jalālain, Hlm. 426-427.

${ }^{15}$ Lien Iffah Naf'atu Fina, "Interpretasi Kontekstual: Studi Pemikiran Hermeneutika Al-Qur'an Abdullah Saeed," ESENSIA: Jurnal Ilmu-Ilmu Ushuluddin 12, no. 1 (22 Januari 2011): 159-180,

${ }^{16}$ Abdullah Saeed, Pengantar Studi al-Qur'an (Yogyakarta: Baitul Hikmah Press, 2018). Hlm. 56. juga banyak dikaji seperti tulisan dari sovia yang berjudul "Interpretasi Kontekstual (Studi Pemikiran Hermeneutika Al-Qur'an Abdullah Saeed)"17. Pemikiran Abdullah Saeed kemudian belakangan dikembangkan dengan konsep yang lebih ringkas oleh Ridwan dengan judul "Metodologi Penafsiran Kontekstual; Analisis Gagasan dan Prinsip Kunci Penafsiran Kontekstual Abdullah Saeed"18. Hal ini membuktikan bahwa Abdullah Saeed memiliki kontribusi pemikiran yang luar biasa dalam hermeneutika atau tafsir kontekstual.

Abdullah Saeed mengemukakan meaning is interactive- bahwa al-Qur'an telah selesai diturunkan seluruh ayatnya utuh 114 surat pada abad ke 7 Masehi, namun maknanya dapat terus digali sampai nanti dengan ditafsirkan kembali secara sistematis dan konstruktif 19. Hermeneutika Abdullah Saeed dapat dipelajari dalam tulisannya, disebutkan bahwa langkah-langkah metodologis hermeneutika dalam menafsirkan secara

${ }^{17}$ Sheyla Nichlatus Sovia, "Interpretasi Kontekstual (Studi Pemikiran Hermeneutika Al-Qur'an Abdullah Saeed)," Dialogia: Jurnal Studi Islam Dan Sosial 13, no. 1 (8 Desember 2016): 51-64,

${ }^{18} \mathrm{M}$. K. Ridwan, "Metodologi Penafsiran Kontekstual; Analisis Gagasan dan Prinsip Kunci Penafsiran Kontekstual Abdullah Saeed," Millati: Journal of Islamic Studies and Humanities, Vol. 1, no. 1 (15 Juni 2016): $1-22$.

${ }^{19}$ Abdullah Saeed, Interpreting the Qur'an: Towards a Contemporary Approach (New York: Outledge, 2006).Hlm. 19. 
kontekstual al-Qur'an terdapat empat langkah. Pertama, perjumpaan yaitu mencari kesesuaian teks dengan mempertimbangkan bahasa dan maknanya sebagai langkah awal. kedua, mengidentifikasi teks dengan menganalisis linguistik dan historis sebagai pemahaman wahyu. ketiga, mengaitkan penafsiran teks dengan konteks dengan meninjau pemikiran mufassir yang termuat dalam kitab tafsir dari generasi ke generasi. Keempat, kontekstualisasi mencari relevansi penafsiran dengan nilai hirarkis ${ }^{20}$. Keempat langkah tersebut yang nantinya akan diterapkan penulis dalam menafsirkan ulang tentang Larangan Ingkar Tanggung Jawab Dalam QS. alȘāffāt : 139-148.

Untuk mencapai makna terdalam dari al-Qur'an terlebih dahulu harus melewati empat metode hermeneutika atau tafsir kontekstual. Pertama, yaitu mencari makna teks awal dengan mencari akurasi dan validitas ayat yang sedang dikaji dalam tema. Kedua, yaitu identifikasi makna teks. Adapun untuk mengidentifikasi makna teks diperlukan tiga langkah. Langkah pertama, menganalisis lingusitik; yaitu setiap bagian-bagian dari suatu teks seperti

20 Abdullah Saeed, Interpreting the Qur'an: Towards a Contemporary Approach.Hln. 23. sintaksis (nahwu), stilistika (gaya bahasa), morfologi (șaraf), semantik (perubahan makna atau tanda), sastrawi (balaghah) pragmatik (kesesuaian bahasa dengan konteksnya). Langkah kedua, analisis historis; asbāb al-nuzūl baik secara mikro yang terdapat dalam hadis maupun riwayat maupun secara makro (sosial, kultural, politik, ekonomi, intelektual, nilai, praktik). Langkah ketiga pemahaman penerima pertama yaitu para sabahat kala itu dan masyarakat Arab pada sekitar abad ke tujuh. Ketiga, mengkaitkan teks dengan konteksnya melalui pengkajian tafsir-tafsir klasik, modern, dan kontemporer. Keempat, kontekstualisasi dengan mengadopsi penafsiran yang relevan. Namun kekurangan dari metode ini mulanya hanya digunakan untuk ayat yang berkaitan dengan hukum saja.

Abdullah Saeed adalah sosok yang menawarkan angin segar dalam dunia intrepetasi. Sebuah cara memaknai alQur'an dengan pendeketan yang lebih rasionalis, namun tidak liberal. Hermeneutika atau tafsir kontekstual yang dikemukakan Abdullah Saeed sangat teliti dengan memperhitungkan aspek kebahasaan sehingga tidak memperkosa ayat al-Qur'an. lebih lanjut, pada pendekatan yang ditawarkan beliau menekankan adanya analisis historis yang 
harus dianalisis secara kritis, sehingga penerimaaan al-Qur'an terlihat jelas, sebab al-Qur'an memiliki keterpengaruhan ruang historis bangsa Arab yang harus disesuaikan, selian itu al-Qur'an juga hadir tidak diruang hampa, didalamnya terdapat ayat yang bersifat temporal dan universal, terdapat ayat muḥkamāt dan mutasyābihāt. Menurut Miftahur Rahman mengemukakan bahwa Abdullah Saeed itu menawarkan istilah hermeneutika ethico-legal yang meliputi aturan syariat, konsep eskatologi (adanya kehidupan setelah kematian), adanya aturan seperti pernikahan, perceraian, warisan, dan hudūd yang meliputi batasan larangan yang harus ditinggalkan. Selain itu terdapat etika dan estetika yang harus dipatuhi dalam hubungan bermasyarakat, beragama, dan bernegara, seperti halnya relasi yang semestinya dijalin baik anatara muslim dan non-muslim ${ }^{21}$. Ayat tersebut sangat dekat dengan dengan kehidupan sehari-hari, bahkan sangat familiar. Oleh sebab metode hermenautika Abdullah Saeed perlu penyesuaian dengan adanya kritik dan saran yang akan disampaikan penulis di bagiam metode.

${ }^{21}$ Miftahur Rahman, “Uli Al-Amr Dalam Alquran: Sebuah Aplikasi Teori Kontekstual Abdullah Saeed," Jurnal Studi Ilmu-Ilmu Al-Qur'an Dan Hadis, Vol. 18, No. 2 (2 Juli 2017), Hlm. 141-162,
3. Kritik Metode Hermenutika Abdullah Saeed: Upaya penyesuaian Interpretasi Dari Ayat Hukum menuju Ayat Kisah

Ayat al-Qur'an tidak hanya berbicara tentang perkara yang legal, theological, ethical. Di dalam kitab suci umat Islam penting memahami pesan alQur'an yang diperuntukkan pada setiaptempat dan zaman, atau bersifat universal.22 Perlunya kesadaran bahwa ayat al-Qur'an memiliki bahasa penyampaian yang menarik berupa kisah. Ayat tersebut merujuk pada tradisi umat dan bangsa-bangsa terdahulu yang kemudian melahirkan peristiwa dalam sejarah manusia. Rekontruksi pemahaman terhadap ayat kisah dapat menggali message of the Qur'an. oleh sebab itu metode Hermeneutika sangat disayangkan jika hanya digunakan untuk mengkaji ayat kisah, sebab dari akar epistemologi hermeneutika Saeed yang diambil dari Rahman sejatinya mengkaji seluruh tema kehidupan yang ada dalam al-Qur'an ${ }^{23}$.

Untuk mengembangkan pemikiran Abdullah Saeed, penulis melontarkan beberapa kritik dan penyesuaian metode. Hal ini dilakukan untuk menyesuaikan

\footnotetext{
Kontekstual.", h. 170.

${ }^{23}$ Lien Iffah Naf'atu Fina, “Interpretasi Kontekstual Abdullah Saeed: Sebuah Penyempurnaan Terhadap Gagasan Tafsir Fazlur Rahman," dalam Jurnal Hermeneutik 9, no. 1 (2015): 65-89.
} 
hermeneutika Saeed yang khusus terhadap ayat ethico-legal dapat diterapkan kepada ayat yang lebih universal. Mengutip istilah uṣul fiqih yaitu syar'u man qablanā adalah adalah syariat dari orang sebelum umat kita, yaitu ayat maupun penjelasan yang diturunkan kepada umat sebelum nabi Muhammad dapat berupa kisah, perumpamaan dan lain macam sebagainya untuk diambil 'ibrah (Pelajaran) ${ }^{24}$. Riwayat-riwayat terdahulu mampu dibuat hukum sebagai pertimbangan umat setelahnya ${ }^{25}$. Dari dua hal tersebut jelas bahwa ayat kisah dapat dibuat dalil atas dasar pengambilan keputusan ${ }^{26}$. Dari hal ini maka metode hermeneutika Abdullah Saeed yang semula memiliki empat metode, akan disederhanakan oleh penulis menjadi tiga metode, Pertama perjumpaan awal dalam al-Qur'an. Kedua mencari makna asal dengan cara analisis linguistik dan historis disertai dengan penjelasan dari para mufassirin. Ketiga kontekstualisasi, untuk mencari singnifikansi dan nilai hirarki (maghzā) dari ayat al-Qur'an. Setiap ayat tentu memiliki salah satu dari obligary values, fundamentalis values, protectional values, implementasi values, instructional

${ }^{24} \mathrm{Abd}$ Wahhāb Khallāf, 'Ilm Ușūl al-Figh (Kairo: Dār al-Kutub al-'Alamiyyah, 1968), 93.

${ }^{25} \mathrm{As}^{\prime}$ ad 'Abd al-Ghani al-Sayyid al-Kafrāwīyy, Istidlāl 'Inda Ușūliyyinn (Kairo: Dār al-Kutub al-Alamiyyah, 2009), 252.

26Mannā' al-Qațtān, Mabāḥis fi 'ulūm al-Qur'an (Kairo: Dār al-Kutub al-'Alamiyyah, 1973), Hlm. 306. values. Dari kelima nilai hirarki tersebut akan dapat dilihat menempatan ayat dalam tingkatan universal atau partikular, dan hermeneutika Abdullah Saeed dipilih penulis sebagai tawaran metodologi untuk mencapai cakupan yang luas dalam menafsirkan kisah yang terdapat dalam alQur'an.

\section{Perjumpaan awal Kisah Nabi Yūnus dalam al-Qur'an}

Sikap para mufassir dalam memaknai kisah al-Qur'an memiliki dua pandangan umum yaitu menafsirkannya dengan makna haqīqī dan majāzi. Pertama, penafsiran kisah al-Qur'an secara haqīi adalah mememahami kisah yang terdapat dalam ayat al-Qur'an sesuai dengan redaksi peristiwa, diyakini bahwa kisah dalam al-Qur'an benar-benar terjadi di dunia nyata pada masa silam. Kedua, penafsiran kisah al-Qur'an secara majāzi adalah pandangan lain dari mufassir, bahwa kisah dalam al-Qur'an adalah perumpamaan yang menjadi bahasa simbolik tetap meyakini adanya kisah dalam al-Qur'an namun bukan dari redaksi yang disampaikan melainkan kandungan nilai yang dapat diambil dari sebuah kisah. Dalam hal ini para mufassir memberikan contoh, misal kisah tentang malaikat dimaknai bukan sebagai makhluk yang dikenal diciptakan dari 
cahaya berwarna putih memiliki sayap, melainkan adalah bentuk simbol dari kebaikan, begitu juga kisah tentang syaitan bukanlah makhluk yang terbuat dari api yang menggoda manusia, namun merupakan perwujudan simbol dari keburukan ${ }^{27}$.

Menyikapi perbedaan pendapat tentang kisah yang dikemukakan para mufassir terdahulu, penulis memiliki pandangan bahwa kisah yang ada di alQur'an merupakan kejadian yang nyata pada masa terdahulu, namun kisah tersebut perlu digali tentang valueyang terdapat didalamnya. Dalam hal ini, penulis mengidentifikasi dan mengkompilasi kisah-kisah nabi Yūnus didalam ayat al-Qur' an untuk mengetahui cerita yang lebih utuh. Secara rinci kisah tentang nabi Yūnus didalam al-Qur'an disebutkan enam kali, yaitu sebagai berikut:

QS. al-Nisā' [4]: 163

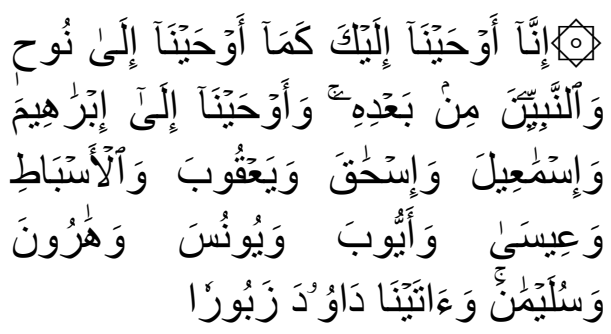

Sesungguhnya Kami mewahyukan kepadamu (Muhammad) sebagaimana Kami telah

${ }^{27}$ Novita Siswayanti, "Dimensi Edukatif Pada Kisah-Kisah Al-Qur'an," SUHUF Jurnal Pengkajian AlQur'an Dan Budaya, Vol. 3, No. 1 (2010): 69-83. mewahyukan kepada Nuh dan nabi-nabi setelahnya, dan Kami telah mewahyukan (pula) kepada Ibrahim, Ismail, Ishak, Yakub dan anak cucunya; Isa, Ayyub, Yunus, Harun dan Sulaiman. Dan Kami telah memberikan Kitab Zabur kepada Dawud. (QS. al-Nisā' [4]: 163)

QS. al-An'ām [6]: 86

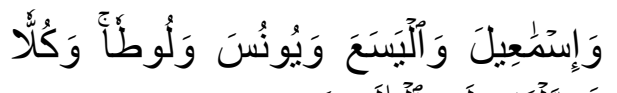

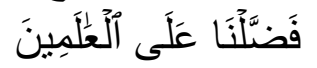

dan Ismail, Alyasa', Yunus, dan Lut. Masing-masing Kami lebihkan (derajatnya) di atas umat lain (pada masanya) (QS. al-An'ām [6]: 86)

\section{QS. Yūnus [10]: 96-98}

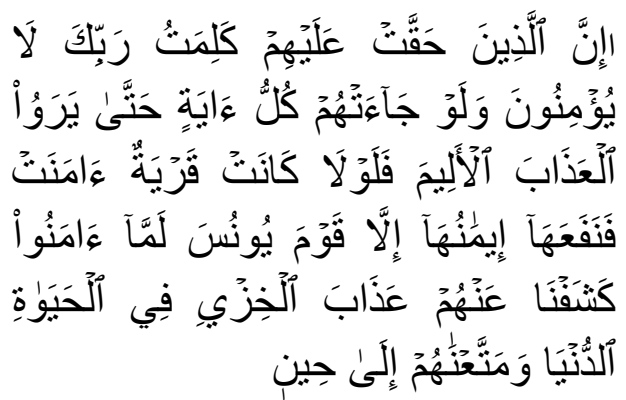

Sungguh, orang-orang yang telah dipastikan mendapat ketetapan Tuhanmu, tidaklah akan berimanmeskipun mereka mendapat tanda-tanda (kebesaran Allah), hingga mereka menyaksikan azab yang pedih. Maka mengapa tidak ada (penduduk) suatu negeri pun yang beriman, lalu imannya itu bermanfaat kepadanya selain kaum Yunus? Ketika mereka (kaum Yunus itu) beriman, Kami hilangkan dari mereka azab yang menghinakan dalam kehidupan dunia, dan Kami beri kesenangan kepada mereka sampai waktu tertentu. (QS. Yūnus [10]: 96-98). 
QS. al-Anbiyā' [21]: 87:

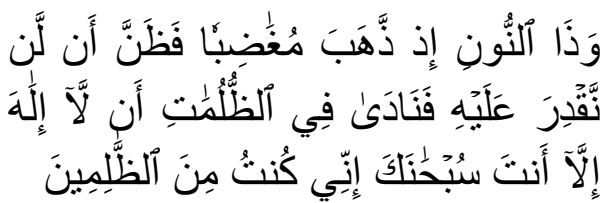

Dan (ingatlah kisah) Zun Nun (Yunus), ketika dia pergi dalam keadaan marah, lalu dia menyangka bahwa Kami tidak akan menyulitkannya, maka dia berdoa dalam keadaan yang sangat gelap, "Tidak ada tuhan selain Engkau, Mahasuci Engkau. Sungguh, aku termasuk orangorang yang zalim." (QS. al-Anbiyā' [21]: 87)

QS. al-Ṣāffāt [37]: 139-148:

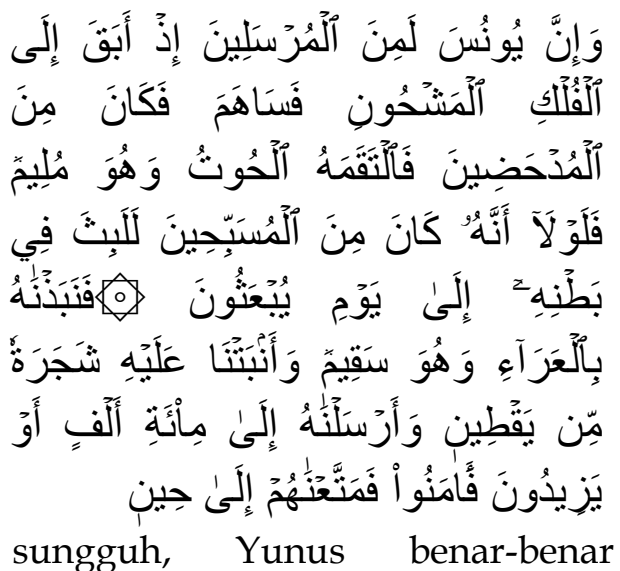
termasuk salah seorang rasul. (ingatlah) ketika dia lari, ke kapal yang penuh muatan. kemudian dia ikut diundi ternyata dia termasuk orang-orang yang kalah (dalam undian). Maka dia ditelan oleh ikan besar dalam keadaan tercela. Maka sekiranya dia tidak termasuk orang yang banyak berzikir (bertasbih) kepada Allah. Niscaya dia akan tetap tinggal di perut (ikan itu) sampai hari kebangkitan. Kemudian Kami lemparkan dia ke daratan yang tandus, sedang dia dalam keadaan sakit. Kemudian untuk dia Kami tumbuhkan sebatang pohon dari jenis labu. Dan Kami utus dia kepada seratus ribu (orang) atau lebih. sehingga mereka beriman, karena itu Kami anugerahkan kenikmatan hidup kepada mereka hingga waktu tertentu. (QS. al-Ṣāffāt [37]: 139148).

\section{QS. al-Qalam [68]: 48:}

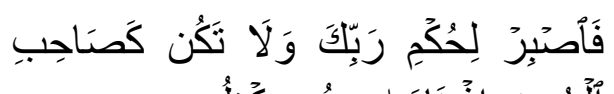

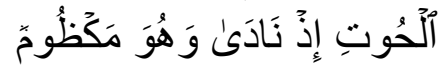

Maka bersabarlah engkau (Muhammad) terhadap ketetapan Tuhanmu, dan janganlah engkau seperti (Yunus) orang yang berada dalam (perut) ikan ketika dia berdoa dengan hati sedih. (QS. alQalam [68]: 48)

Dari seluruh ayat yang telah disebutkan diatas ayat yang memiliki informasi paling lengkap adalah QS. alṢāffāt [37]: 139-148. Oleh sebab itu penulis tidak akan membahas secara keseluruhan satu persatu ayat diatas, melainkan memaparkan penjelasan ayat yang dirasa memiliki informasi paling lengkap yaitu dalam QS. al-Ṣāffāt : 139-148. Pemilihan QS. al-Ṣāffāt [37]: 139-148. Sebagai studi objek formal tersebut didasari penulis atas adanya studi komparatif intratekstualitas antara kitab Jonah dengan kisah nabi Yūnus dalam QS. al-Ṣāffāt [37]: 139-148 yang dilakukan Afsar Ayz yang berjudul "A Comparative Study of the Art of Jonah/Yūnus Narrative in the Bible and 
the Qur'ān" 28. Menurut Afsar kisah tentang Jonah menginspirasi budaya masyarakat Barat untuk senang melangsungkan hidup dengan mengungjungi tempat-tempat yang lebih indah dan nyaman dari masalah, sebagaimana dapat dilihat dalam bibel Jonah:

Now the word of the Lord came to Jonah the son of Amit'tai, saying, (1)"Arise, go to Nin'eveh, that great city, and cry against it; for their wickedness has come upbefore me." (2) But Jonah rose to flee to Tarshish from the presence of the Lord. He went down to Joppa and found a ship going to Tarshish; so he paid the fare, and went on board, to go with them to Tarshish, away from the presence of the Lord (3), (Jonah [1]: 1-3) 29

Mendiskusikan tentang kisah merupakan hal yang sudah lama dalam isu menarik dalam kajian tafsir dan 'ulūmul Qur'an. Barangkali jika ditinjau hampir tidak ada yang tidak suka mengenai kisah, kisah merupakan cara mengekspresikan diri dengan tokoh-tokoh

${ }^{28}$ Ayaz Afsar, "A Comparative Study of the Art of Jonah/Yūnus Narrative in the Bible and the Qur'ān," t.t., 22.

${ }^{29} Y$ vonne Sherwood, A Biblical Text and Its Afterlives: The Survival of Jonah in Western Culture (Cambridge University Press, 2000). yang berperan didalamnya, sehingga dapat dipetik sebuah 'ibrah atau pelajaran. Dalam hal ini sudah tidak terhitung lagi bagaimana sebuah kisah nabi Yūnus dikaji di perguruan tinggi, di dalam forum diskusi, di dalam pengajian, dan dimuat dibanyak tulisan. Dapat dilihat tulisan Iskandar yang berjudul "Makna Teologis Respon Nabi Yūnus Terhadap Panggilan Tuhan" didalamnya membahas bagaimana perjalanan nabi Yūnus dalam versi perjanjian lama ${ }^{30}$. Hal ini kemudian menjadi menarik bahwa kisah nabi Yūnus termuat dalam kitab suci terdahulu, adapun al-Qur'an secara langsung juga memiliki menceritakan cerita sama yang diketahui oleh tradisi agama lainnya namun dengan versinya yang berbeda.

\section{Analisis lingusitik: telaah kisah nabi} Yūnus dalam QS. al-Ṣāffāt: 139-148

Untuk menganalisis historis Abdullah Saeed mengemukakan supaya merujuk pada kamus Lisān al-'Arab, sebab dalam kamus tersebut dipadang oleh Abdullah Saeed sebagai kamus yang berhasil merekam makna kata-kata tersebut pada masa itu yaitu al-Qur'an, tentu berbeda jika dibandingkan dengan kamus yang sekarang, selain itu merujuk karya tafsir dari masa kemasa untuk

${ }^{30}$ Yimmy Iskandar, "Makna Teologis Respon Nabi Yunus Terhadap Panggilan Tuhan," Jurnal Teologi Berita Hidup, Vol. 2, No. 1, Hlm. 28-35. 
melihat singkronik dan diakronik dari suatu makna yang ada. Penafsiran larangan inkar tanggung jawab yang terdapat dalam kisah tentang nabi Yūnus setidaknya harus mengkaji lima belas aspek linguistik teks. Dalam ayat wainna Yūnusa laminal mursalīn, makna yang harus digali adalah kata mursalin, dalam kamus Lisān al-'Arab makna mursalīn memiliki dua makna, dari bentuk asal kata arsala kemudian menjadi isim maf'ul yang kemudian dijama' mużakar sālim dari kata mursalun kemudian sebab ber'irab nașab ditambah 'alamah i'rab huruf ya' dan nun. Makna yang pertama berarti orang-orang yang diutus. Sedangkan makna yang kedua mursalīn dimaknai dengan taannā yaitu orang yang tidak tergesa-gesa dan bertindak perlahan.

Pada Ayat iż abaqa ilalfulki almasyḥūn. Kata abaqa menurut Lisān al'Arab dimaknai sebagai harbu al-'abid wa dzahabuhum, qātị' min 'amalin bi ghairi khaufin yang artinya orang yang lari dari penghambaan dan pergi dari tanggung jawab, atau orang yang memutus sebuah pekerjaaan tanpa adanya ketakutan. Kemudian ilal fulki lafaz al-fulki berbentuk ma'rifat yang memiliki artinya kendaraan yang ada di laut.

Analisis ayat fasāhama fakāna min almudhadìn. Pada ayat ini makna sāhama menurut kamus Lisān al-'Arab adalah al-
Qur'ah yang bermakna, undian yaitu iltagat naslan berpartisipasi mengambil mata tombak sebagai penentu nasib ${ }^{31}$. Lafaz fakāna adalah dua kalimat yang terdirir dari $f a$ huruf jawab dari $f a$ syartiyyah dari lafaz fa sāhama, sedangkan kāna adalah 'āmil lafại yang masuk pada mubtada yang menjelaskan tentang suatu kejadian yang telah lampau, sehingga maknanya adalah maka nabi Yūnus kemudian menjadi seseorang. Lafaz selanjutnya adalah min al-mudhadìn, kata mudhaḍin merupakan bentuk jama' dari isim fä'il mufrad yaitu kata mudhadun yang berarti orang yang dibuang, sehingga dapat dipahami bahwa nabi Yūnus telah kalah dalam undian berkali-kali, sebab kata yang dipakai berbentuk jama'. Dalam cerita Nabi Yūnus diceritakan Abu Bakar Ibn al-'Arabi membagi cerita ini atas empat hal. Pertama, nabi Yūnus merupakan utusan dari Allah rabbul ālaminn. Kedua, nabi Yūnus diutus di kaum Nainawa yang bayangannya adalah kaum yang mengikuti adat mempercayai utusan, namun ternyata kaum Nainawa malah menyembah berhala, yang menjadikan nabi Yūnus itu marah dan kemudian berdoa agar kaumnya di Adzab. Ketiga, orang zaman dahulu memutuskan siapa yang benar dan bersalah itu dari

${ }^{31}$ Ibn Manẓur, Lisānul Arab (Beirut: Dār al-Kutub al-'Alamiyyah, 2008). Juz 19. Hlm 26. 
keberuntungan dengan cara melakukan undian, yang kalah dalam undian adalah bersalah. Keempat, undian dalam memutuskan hukum terhadap manusia itu tidak diperbolehkan, sebab hukuman atau hudīd itu dijatuhkan sesuai dengan jināyah yang dilakukan ${ }^{32}$.

Analisis ayat faltaqamahu al-ḥutu wahuwa mulim. Kata iltaqama memiliki makna menelan bulat-bulat, lafaz iltaqāmahu dalam kamus lisān al-Arab memiliki makna muttasa'u aldākhilati(luasnya sesuatu yang masuk), sedangkan huruf $f a^{\prime}$ diawal adalah $f a^{\prime}$ jawab dan ḍāmir diakhir merupakan dạmir mufrad mużakkar ghayb yang merujuk kepada nabi Yūnus ${ }^{33}$. Lafaz al-ḥutu dalam kamus lisān al-Arab huwa al-samaku alkabiru adalah ikan yang berukuran besar, mungkin zaman sekarang dapat berupa paus, atau hiu putih ${ }^{34}$. Sedangkan lafaz mulìm merupakan isim fä́il dari kata alāma yang berarti 'ażallah yaitu orangorang yang tercela atau dikecam ${ }^{35}$

Analisis ayat falaulā annahu kāna mina al-musabbiḥin dan lalabisa fi baṭnihì ilā yaumi yub'asiūn.keduanya merupakan ayat yang berstatus syarat dan jawab. Ayat ini falaulā annahu kāna mina al-musabbihīn

${ }^{32} \mathrm{Abu}$ Bakar Ibn al-Arabi, Ahkam al-Qur'an (Libanon: Dār al-Kutub al-'Alamiyyah, 2008). Juz. 1. Hlm. 573.

\footnotetext{
33 Ibn Manzur, Lisānul Arab. Juz. 14. Hlm. 245

${ }^{34} \mathrm{Ibn}$ Manẓur.Lisānul Arab. Juz. 2. Hlm. 26.

${ }^{35}$ Ibn Manẓur.Lisānul Arab. Juz. 14. Hlm. 40.
}

menurut mufassir generasi klasik memiliki munāsabah dengan QS. alAnbiyā' [21]: 87 menjadi syarat dan jawabnya adalah ayat lalabisia fi baṭihī ilā yaumi yub'as̄ūn.Menurut penafsiran dari Muqātil Ibn Sulaiman mengemukakan bahwa setiap seseorang yang melakukan tindakan ceroboh akan dihukumi sebagai mulim sampai kemudian menyesali perbuatannya dan memperbaiki baik secara zāhir maupun bāṭin.Dalam tafsir muqātil Ibn Sulaiman dikatakan bahwa yang dimaksudkan dalam cerita nabi Yūnus adalah pelajaran i'tiraf. I'tiraf adalah pengakuan kesalahan secara objektif dalam perilaku, apabila memiliki tanggung jawab dilakukan sebaik mungkin, namun jika terjadi kesalahan dan ingkar terhadap hal tersebut kemudian diakui dengan didampingi penebusan atas tanggung jawab yang telah ditinggalkan, sebagaimana yang dilakukan nabi Yūnus menebus kesalahan berdzikir dengan membaca tasbih, lāilahailla anta subḥānaka innī kuntu min alzālimin ${ }^{36}$.

Dari sebab pertaubatan dengan membaca tasbih diatas maka nabi Yūnus kemudian diselamatkan Allah dari perut ikan besar, namun apabila tidak maka nabi Yūnus akan terus berada di dalam

${ }^{36}$ Muqātil Ibn Sulaiman, Tafsìr Muqātil Ibn Sulaiman (Beirut: Dār al-Fikr al-Islāmy, 1998). jilid 1, hlm. 236 
perut ikan besar tersebut sampai hari kebangkitan. Imam al-Ṭabarī dalam tafsirnya menjelaskan bahwa doa lāilahailla anta subhānaka inn̄̄ kuntu min al-zālimin merupakan doa yang mampu sampai 'Arsy37. Dalam kitab Mujma' al-Zawāid juga dijelaskan bahwa lāilahailla anta subhānaka innī kuntu min al-zālimin merupakan sebuah kalimat yang dapat menolong manusia dari siksa ${ }^{38}$. Analisis ayat fanabażnāhu bil 'arāi wahuwa saqim.Lafaz nabaża memiliki arti ramyu yaitumelemparkan, huruf $\mathrm{fa}^{\prime}$ tersebut merupakan fa' fāṣịhah dari ayat falaula annahu kāna mina al-musabbiḥin dan lalabis̀a fi baṭnihī ilā yaumi yub'as̀ūn. kemudian al-'arāi memiliki makna pesisir atau tanah kosong, selanjutnya makna saqīm dari kata saqama yang bermakna sakit namun mengikuti wazan fa'îlun

${ }^{37} \mathrm{Abu}$ Ja' far Muhammad Ibn Jarīr al-Ṭabarī, Jāmi' al-Bayān fi Tafsìr al-Qur'ān (Beirut: Dār al-Kutub al'Alamiyyah, 2003). J. 19. H. 628.

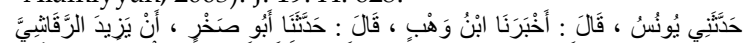

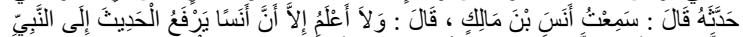

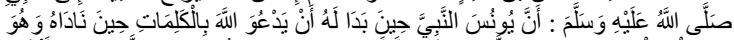

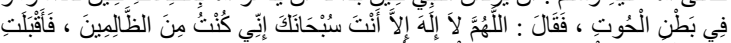

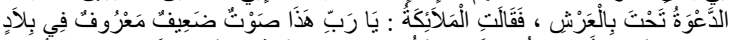

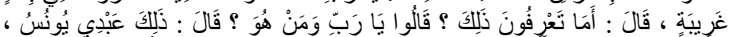

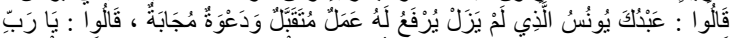

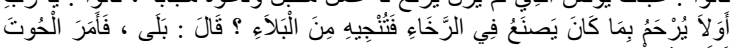

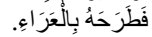

${ }^{38} \mathrm{Abu}$ Bakar Nuruddin 'Ali Ibn Abi Bakar Sulaiman Haiṡamī, Mujma' al-Zawāid (Beirut: Dar Ibn alQayyim, 1998). Juz 14, hlm 19.

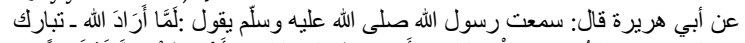

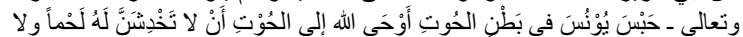

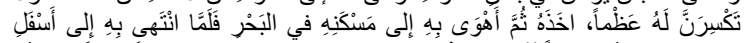

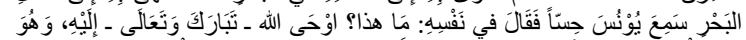

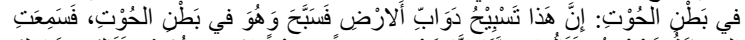

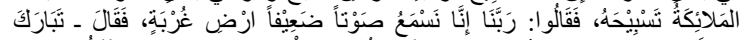

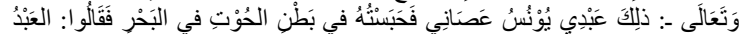

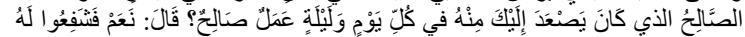

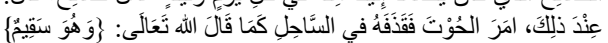

yang memiliki faidah taysdīd yaitu sakiit yang sangat 39 .

Analisis ayat wa anbatnā 'alaihi syajaratan min yaqtīn, wa arsalnāhu ilā miati alfin aw yazìdūn, faāmanū famatta'nāhum ilā hìn.Tiga ayat yang telah disebutkan diatas menurut Imam fakhruddin al-Rāzi mengemukakan bahwa ayat tersebut memiliki dua pemahaman. Pemahaman pertama disebut pemahaman denotatif (al$m a^{\prime} n a$ al-żāhir) dan yang kedua adalah makna konotatif (al-ma'na al-bātịn $)^{40}$. Pada pemahaman pemaknaan denotatif yaitu nabi Yūnus setelah dikeluarkan dari mulut ikan besar maka dengan keadaan yang belum pulih kemudian sedang berbaring, lantas diatasnya tumbuh buah yang merambat yaitu syajaratan min yaqtin, para ulama banyak berbeda pendapat dalam mendefiniskan ada yang mengatakan labu, melon, ada juga semangka, kemudian dijemput kaumnya yang sudah dalam keadaan Islam karena takut akan datangnya azab dari Allah, kemudian nabi Yūnus dan kaumnya yang berjumlah seratus ribu lebih dapat hidup tenang bahagia. Sedangkan pada pemahaman pemaknaan konotatif ketiga ayat tersebut merupakan kiasan bahwa seseorang yang

${ }^{39}$ Al-Imam al-Ālim al-'Allamah al-Habru alBahru al-Fahmah Fakhruddin Muhammad Ibn 'Umar alTamīmī al-Razi, Mafätih al-Ghaib (Beirut: Dār al-Kutub al'Alamiyyah, 1998).juz 21, hlm. 129-130. Hlm.131. 
sudah menjalani hukuman maka akan mendapatkan kebebasan dan kenikmatan menjalani kehiduapan secara tenang tanpa adanya kegelisahan.

\section{Anlisis Historis: Mengungkap Asbābun} Nuzūl Makro-Mikro QS. al-Ṣāffāt : 139148

Salah satu upaya untuk mendekati makna yang lebih valid adalah dengan memastikan konteks historis dari suatu ayat. Dalam hal ini 'ulūmul qur'an telah memberikan pandangan yang menarik yaitu al-'ibrah bikhuṣus al-sabab la bi 'umūm al-lafaż yaitu rumusan tentang mempertimbangkan

kekhususan sebabnya ayat bukan lafaznya, dan al'ibrah bi 'umūm al-lafaż la bikhuṣus alsabab yaitu rumusan tentang keumuman lafaz yang dipertimbangkan bukan kekhususan sebabnya. Para ulama' memiliki pandangan yang berbeda dalam hal ini, namun penulis cenderung mengikuti paham yang kedua, dengan ditambah bahwa al-Qur'an selalu tadarruj (bertahap) dalam berdakwah. Oleh sebab itu untuk melihat bagaimana konteks historis dari kisah nabi Yūnus dalam QS. al-Ṣāffāt [37]: 139-148 berikut adalah asbābun nuzūl baik secara mikro maupun makro.
Dalam ayat kisah ini penulis belum hanya menemukan asbāb al-nuzil makro, sedangkan yang mikro belum ditemukan. Untuk itu adapun asabāb al-nuzūl secara makro dapat diketahui lewat kajian makkiyyah dan madaniyyah. Sebagaimana dikemukakan oleh 'Ābed al-Jābirī dalam kitab al-Madkhal ilā al-Qur'ān al-Karìm: al-Juz al-Awwal fi Ta'rīf bi al-Qur'ān $n^{41}$, mengatakan bahwa al-Qur'an dapat dibaca dengan dua versi qirä'ah al-Qur'ān bi al-șirah wa qirā'ah al-șirah bi al-Qur'ān yaitu membaca al-Qur'an dengan kisah nabi dan membaca sirah nabi dengan melihat al-Qur'an. Dalam mengidentifikasi makna 'Ābed al-Jābirī memberikan pandangan memahami teks dengan kaidah Jā'il al-Qur'an mu'āṣiran linafsih wa mu'asiran lanā yaitu menjadikan al-Qur'an dipahami pada zamannya dan menjadikan al-Qur'an dipahami dizaman kita. Hal ini bertujuan mengungkap arti penting dari da'wah muhammadiyyah dengan melihat karangannya yang berjudul Fahm al-Qur'ān al-Hakìm: al-Tafsìr al-Wādih Hasba Tartīb al-Nuzūl 42. Menurut pandangan 'Ābed al-Jābirī dalam kitab Fahm al-Qur'ān al-Hakìm: al-Tafsìr al-Wāẹih Hasba Tartīb al-Nuzūl. Surat QS. al-Ṣāffāt [37]: 139-148 turun pada saat nabi berada

\footnotetext{
41' Ābed al-Jābirī, Madkhal ilā al-Qur'ān al-Karìm: al-Juz al-Awwal fi Ta'rîf bi al-Qur'ān (Beirut: Markaz Dirāsat al-Waḥdah al-'Arābiyyah, 2006). 201

42al-Jābirī 'Ābed al-Jābirī, Madkhal ilā al-Qur'ān al-Karìm: al-Juz al-Awwal fi Ta'rīf bi al-Qur'ān,.202.
} 
di Makkah yaitu sebelum nabi hijrah ke Madinah, dan sebelum nabi hijrah ke Habasyah dalam konteks fase asbābun nuzūl ini 'Ābed al-Jābirī menempatkan pada Makkiyyah kedua pada saat al-Ṣad' bi al-Amr wa al-Ittisal bi al-Qabā'il yaitu nabi dihalang-halangi dakwahnya dan bersatunya para suku untuk membantu nabi ${ }^{43}$.

Jika dilihat dari Pandangan pertama penerima wahyu maka dapat ditarik kepada bingkai pemahaman yang lebih luas lagi. Bangsa Arab di zaman Nabi Muhammad terdiri dari berbagai suku. Didalam suku sistem kelas ini memegang berbagai aspek kehidupan seperti sosial, politik, ekonomi. Untuk bertahan hidup pada masa itu perlu kesepakatan yang luar biasa supaya kehidupan berjalan seimbang stabil tanpa adanya konflik, hal ini kemudian menjadi situasi yang sangat berbahaya dan krusial apabila seseorang yang memiliki tanggung jawab dipercaya dalam sebuah suku kemudian melakukan pengingkaran. Dampak terburuk dari hal tersebut adalah peperangan yang akan menjadikan pertumpahan darah, korban dimanamana, anak kecil tanpa orang tua, wanita tanpa suami dan menjanda, stabilitas

${ }_{43}^{4}$ Ābed al-Jābirī, kitab Fahm al-Qur'ān al-Hakim: al-Tafsìr al-Wādih Hasba Tartỉb al-Nuzūl. (Beirut: Dār alSyurūq, 2010). Hlm. 207 keamanan terganggu, sumber daya alam diekploitasi, rasa kepedulian sosial menjadi sangat langka. Itulah sebabnya larangan untuk ingkar terhadap tanggung jawab yang telah diamanahkan, hal ini secara tidak langsung menyinggung masalah situasional yang terjadi waktu nabi Muhammad SAW.

Nabi Muhammad digelari al-Amīn merupakan hal yang spektakuler. Jika dimaknai secara biasa nabi Muhammad adalah orang yang diberi gelar sangat sederhana, jika dibandingkan dengan nabi-nabi lainnya. Bayangkan nabi Musa adalah kalìmullah, nabi Ibrāhīm adalah khalilullah,nabi 'Isa adalah al-Masih,dan masih banyak lainnya. Namun coba menilik nabi Muhammad gelarnya sederhana yaitu al-'abdu yang berarti seorang hamba, dan al-Amin yang berarti orang yang dapat dipercaya, namun dibalik gelarnya yang sederhana nabi Muhammad mengemban tugas mendakwahkan Islam kepada seluruh alam semesta, tidak peduli umatnya yang semasa pada zamannya, maupun umatnya yang belakangan diakhir zaman. Oleh sebab itu, nabi Muhammad SAW. hadir sebagai orang yang dapat dipercaya yang sabdanya dapat dikultuskan, dipegangi dengan sangat kuat sebagai suri tauladan dan tuntunan dalam setiap aspek kehidupan. 


\section{Kontekstualisasi: Upaya Menggali Singnifikansi dan Nilai Hirarki Dari Kisah Al-Qur'an}

\section{Singnifikansi Turunnya Ayat di Masa Nabi Muhammad SAW.}

Setiap ayat diturunkan tentu memiliki kepentingan yang melingkupi di belakangnya. Menurut Saeed sebuah ayat hadir untuk memberikan petunjuk bagi umat manusia secara universal baik yang berasal dari bangsa Arab maupun bangsa 'Ajam4. Lebih lanjut lagi pentingnya melihat literatur dalam tafsir yang telah disusun ulama' sebagai acuan analisis untuk mendapatkan pemahaman yang komprehensif ${ }^{45}$. Melihat siginifikansi ayat adalah upaya untuk mendapatkan bagaimana ayat al-Qur'an hadir memberikan sebagai spirit kepada nabi Muhammad SAW. pada abat ke tujuh lalu. Oleh sebab itu signifikansi dari QS. alṢāffāt : 139-148 dapat dilihat dalam kitab tafsir al-tahrīr wa al-tanīr karya Ibnu ‘Asyūr yaitu sebagai berikut ${ }^{46}$ :

${ }^{44}$ Saeed, Interpreting The Qur'an: Towards A Contemporary Approach. Hlm. 54

${ }^{45}$ Sahiron Samsudin, "Pendekatan Dan Analisis Dalam Penelitian Teks Tafsir:," Suhuf Jurnal Pengkajian AlQur'an Dan Budaya, Vol. 12, No. 1 (28 Juni 2019), Hlm. 131-149,

${ }^{46}$ Muhammad Al-Ṭāhir Ibn 'Āsyūr, Al-Tahrīr Wa Al-Tanwir (Tunisia: Dar Al-Tunisiyya, 1984), J. 23, H. 178.
واعلم أن الغرض من ذكر يونس هنا تسلية النبيء

صلى الله عليه وسلم فيما يلقاه من ثقل الرسالة بأن ذللك قد أنقل الرسل من قبله فظهرت مرتبة النبيء صلى الله عليه وسلم في صبره على ذلك و عدم تذمره و لإعلام جميع الناس بأنه مأمور من الله تعالى فلى دلى

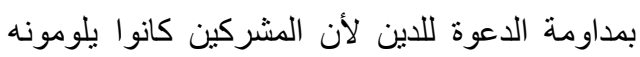
على إلحاحه عليهم ودعوته إياهم في مختلف الأزمان و الأحوال ويقولون: لا تغشنا في مجالسنا فمن جاءك الك الكان

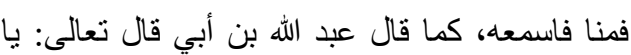
أيها الرسول بلغ ما أنزل إليك من ربك وإن لم تفعل فما بلغت رسالاته [المائدة: 67] فلذكر قصة بونس أثر من موعظة التحذير من الوقوع فيما وقع فيه يونس من غضب ربه ألا ترى إلى قوله نعالى: فاصبر لحكم ربك ولا تكن كصاحب الحوت إذ نادى و هو مكظوم لو لا أن تداركه نعمة من ربه لنبذ بالعر اء

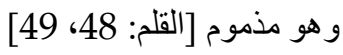
Ketahuilah sesungguhnya signifikansi dari menuturkan kisah dari Nabi Yūnus disini adalah untuk menghibur nabi Muhammad SAW. dalam mendapati keberatan dari menyampaikan risalah. sebab sesungguhnya sangatlah berat juga tugas nabi terdahulu dalam menyampaikan risalah kepada umat. Kemudian jelaslah posisi nabi Muhammad SAW dalam bersabar atas kondisi demikian, dan tidak adanya menggerutu dalam memberikan pengajaran kepada seluruh umat manusia, sebab hal tersebut adalah perintah Allah untuk senantiasa selalu 
berdakwah agama. karena sesungguhnya kaum kafir Qurasy yang sering mengejek atas dakwah nabi Muhammad SAW di berbagai tempat dan waktu. Orang-orang kafir Qurasy mengatakan kepada nabi demikian: "janganlah mencampuri dalam majlis kami apabila kamu datang maka hanya cukup menjadi pendengar saja." Seperti halnya Abdullah Ibn Ubay kemudian berkata, Allah kemudian menurunkan Ayat: “Wahai Rasul! Sampaikan apa yang diturunkan Tuhanmu kepadamu. Jika tidak engkau lakukan (apa yang diperintahkan itu) berarti engkau tidak menyampaikan amanat-Nya". (QS. alMāidah [5]:67). Maka kemudian menuturkan kisah nabi Yūnus adalah sebuah napak tilas dari nasehat sebagai bentuk perhatian di masa sekarang sebagaimana yang telah di alami oleh Nabi Yūnus yang mendapatkan kemurkaan dari Tuhannya, ingatlah sebuah demonstrasi dari firman Allah Ta'āla yaitu. “Maka bersabarlah engkau (Muhammad) terhadap ketetapan tuhanmu, dan janganlah engkau seperti (Yūnus) orang yang berada dalam (perut) ikan ketika bedia dengan sedih hati (QS. al-Qalam [68]: 49-49).

Dari kutipan Imam Ibn Āsyūr diatas maka terlihat jelas bahwa seluruh cerita nabi Yūnus memiliki setidaknya tiga signifikansi untuk dakwah nabi kepada bangsa Arab dan juga dakwah agama umat Islam secara khusus. Signifikansi pertama, seseorang harus amanah dalam menjalankan tanggung jawab sesuai perintah dari atasan, sebab apabila tidak sesuai menjalankan tanggung jawab, maka akan mendapati hukuman sebagaimana nabi Yūnus yang dilahap ikan. Signifikansi kedua, seseorang harus bersabar menghadapi cemooh, ejekan, ketika mendakwahkan agama, sebab yang dinamakan dakwah selalu berat sehingga membutuhkan kesabaran ekstra dalam menjalaninya, dakwah harus dilakukan dengan pendekatan yang ramah bukan dengan pendekatan yang marah. Signifikansi ketiga, sebuah kesalahan dapat ditebus dengan adanya kesungguhan hati, apabila dalam melakukan tanggung jawab terdapat sesuatu yang tidak tepat, maka sesegera mungkin untuk memperbaikinya, sebagaimana nabi Yūnus yang mengakui kesalahan dengan taubat yang serius, hal tersebut terdemonstrasikan secara jelas dalam QS. al-Qalam [68]: 49-49. 
Nilai Hirarki dalam QS. al-Șāffāt : 139148 Tentang Kisah Nabi Yūnus

\section{Tidak Lari dari Tanggung Jawab Yang} Telah Diamanahkan

Meskipun QS. al-Ṣāffāt : 139-148 bercerita tentang kisah nabi Yūnus, namun secara implisit dan simbolik pemahaman ayat tersebut dapat dijustifikasi tentang larangan inkar tanggung jawab dalam menjalankan perintah. Telah dijelaskan bahwa dalam al-Qur'an yang menjelaskan tentang ingkar tanggung jawab adanya penggunaaan lafaz abaqa secara asal makna berarti pergi tanpa izin. Imam alTabari menafsirkan bahwaseorang Nabi harus mudāwamah(untuk senantiasa) bersabar dalam berdakwah kepada umatnya, supaya tidak lari dari tanggung jawab, Imam al-Tabari mengungkapkang dengan la yajūzu yamurru 'an da'wah alummah (tidak diperkenankan seorang utusan pergi dari tugas dakwah kepada umatnya). ${ }^{47}$ Dalam hal ini jelas pada cerita Nabi Yūnus menggunakan kata abaqa yang artinya lari dari tugas penghambaan karena tidak kuasa melihat kaum 19, hlm. 264.
Nainawa, kemudian pergi menuju kapal untuk pergi jauh meninggalkan kaum Nainawa, sampai kemudian ketahuan menjadi penumpang gelap dengan cara diundi yang akhirnya diceburkan ke laut dan di lahap ikan yang besar dan panjang barangkali sejenih ikan paus. Al-Suyūti mengungkapkan sebuah penafsiran menarik. Dalam tafsir al-Jalālain Imam alSuyūti memberikan uraian yaitu huna 'abdun abaqa min sayyidihi tużhiruhu alQur'ah yang berarti Nabi Yūnus adalah seorang hamba yang melarikan diri (ingkar) dari tuannya akan diperlihatkan akibatnya ${ }^{48}$. Bahwa dalam cerita nabi Yūnus adalah sebuah penggambaran tentang seorang hamba atau utusan yang lari dari tanggung jawab tuannya yaitu Allah SWT. maka akan diperlihatkan nasibnya kemudian. ${ }^{49}$

Ahmad Mushthafa Al-Maraghi dalam tafsir al-Marāghi, mengemukakan bahwa dalam cerita nabi Yūnus terdapat dua hikmah penting yang dapat dipetik. Pertama, al- larangan inkar dari tanggung jawab secara eksplisit, namun tindakan lari dari tanggung jawab adalah hal yang tidak boleh dilakukan sebagaimana meninggalkan tanggung jawab yang telah dimandatkan oleh tuannya, atau atasan,

48al-Mahalli dan al-Suyuti, Tafsir Jalālain, Hlm. ${ }^{49}$ al-Mahalli dan al-Suyuti.Tafsir Jalālain, Hlm. 
dalam cerita ini adalah Nabi Yūnus yang diberikan khitāb oleh tuannya yaitu Allah SWT namun malah berbeda dengan yang diperintahkan Allah. itulah sebabnya menurut Ahmad Mushthafa Al-Maraghi nabi Yūnus tidak termasuk golongan ulū al-'Azmi yang kuat dan tahan terhadap menghadapi kondisi umatnya yang tidak taat. Kedua, sebuah hikmah yang dapat dipetik dari kisah nabi Yūnus adalah ketaatan akan berbuah dengan kebahagiaan. Sebagaimana yang dilakukan nabi Yūnus ketika lari dari tanggung jawab dan dilahap ikan, nabi Yūnus kemudian menyesali segala sesuatu perbuatan yang telah dilakukan dengan meningglkan kaum Nainawa, perihal demikian, nabi Yūnus juga menjadi sebab adanya azab atas kaumnya sendiri karena tidak tahan dengan perilaku yang mereka lakukan dengan menyembah berhala. Oleh sebab itu nabi Yūnus kemudian menyesali dan mulai membersihkan diri dengan bertasbīh kepada Allah dengan sungguh-sungguh, sampai akhirnya Allah mengabulkan doa nabi Yūnus dengan menyadarkan kaum Nainawa, dan kembali berdakwah sesuai perintah, sesuai dengan pendapat Syaikh alMaraghi bahwa nabi Yūnus pada saat itu qad kāna yarju rị̣āhu 'azza wajalla ( sangat membutuhkan atas rida Allah SWT.). ${ }^{50}$

\section{Tidak Menyalahgunakan Wewenang}

Menurut sahabat Ibn Abbas dengan tafsir yang berjudul tanwir almiqbas fi tafsìr Ibn Abbas, kaitannya dalam penafsiran kisah nabi Yūnus dalam alQur'an maksudnya adalah seseorang haruslah menghadapi tanggung jawab yang telah diberikan kepadanya, mundur dari posisi tanggung jawab dapat dianggap bersalah, sehingga berhati-hati dalam menerima tanggung jawab adalah hal yang perlu diperhatikan, namun apabila dapat menerima tanggung jawab dengan baik maka akan mendapatkan kenyamanan di akhirat, namun sebaliknya apabila ingkar terhadap tanggung jawab akan menjadi orang yang hina. Hal ini terlihat dalam redaksi ayat ilā al-fulki almasyḥūn, yaitu pelarian nabi Yūnus menuju kapal yang penuh muatan, padahal jika dilihat dari asbāb al-nuzūl ayat, nabi Yūnus seharusnya berdakwah di daerah Nainawa. Hal ini menunjukkan adanya penyalahgunaan wewenang, tujuan utama adalah menjadi rasul, namun ditinggal menuju tempat lain, hal

${ }^{50}$ Ahmad Muștafa Al-Marāghi, Tafsir Al-Marāghi (Beirut: Dār al-Sya'ab, 1998). Juz, 6. Hlm. 278. 
ini sekaligus menjadi kritik kepada dewan pemimpin dan Pemerintah untuk tidak mudah meninggalkan wewenang yang tidak berhubungan dengan umat, sebab hal tersebut dapat dikategorikan tindakan penyalahgunaan wewenang yang jelas dilarang dalam al-Qur'an ${ }^{51}$. Menurut Sayyid Qutb dalam ayat ini orang yang dengan sengaja muhmalah bi mașālih alnās (lalai terhadap kesejahteraan umat) maka dapat dihukum. ${ }^{52}$ Oleh sebab itu sudah sangat tepat di masa sekarang orang yang menyalahgunakan wewenang untuk dipenjara dengan setimpal, sebagaimana nabi Yūnus juga di penjara dalam perut ikan pada saat itu.

\section{Sabar dan Santun dalam Berdakwah Menghadapi Umat}

Setelah bersabar dan melakukan dzikir tasbih maka nabi Yūnus kemudian mendapatkan titik terang dalam berdakwah di kaum Nainawa. Hal ini menunjukkan bahwa berdakwah memerlukan strategi yang baik, al-Qur'an mengajarkan untuk senantiasa berdakwah dengan sabar dan santun, perlahan dan penuh tahapan, dakwah yang arogan akan menjadikan umat merasa tertekan dan pesan dakwah menjadi tidak

\footnotetext{
${ }^{51}$ Ali bin Abi Thalhah, Tafsir Ibnu Abbas (Jakarta: Pustaka Azzam, 2009). Juz. 2, Hlm. 203

52Sayyid Quthb, Tafsir Fi Zhilalil Qur'an Di Bawah Naungan Al-Qur'an, (Jakarta: Gema Insani Press, 2011). Juz. 2. Hlm. 365.
}

tersampaikan, sebaliknya jika dakwah menggunakan pendekatan yang lembut besar kemungkinannya akan tercapai. Hal ini sebagaimana dalam QS. al-al-Ṣaffāt "Maka sekiranya Nabi Yūnus tidak termasuk orang yang banyak berzikir (bertasbih) kepada Allah. Maka Allah dalam redaksinya menggunakan lam taukìd yang bermakna penguatan dan keniscayaan, yang berarti nabi Yūnus akan tetap tinggal di perut (ikan itu) sampai hari kebangkitan. Namun sebab kegigihannabi Yūnus dalam bersabar dan berdakwah secara santun akhirya nabi Yūnus kemudian dilemparkan ke daratan yang tandus dan selamat, sampai akhirnya nabi Yūnus berhasil mengislamkan setidaknya seratus ribu (orang) sehingga kaum Nainawa beriman, karena itu Kami anugerahkan kenikmatan hidup kepada mereka hingga waktu tertentu. Hal ini sekaligus sebagai kritik kepada kelompok yang berdakwah dengan cara kekerasan dan arogan, satu hal yang digaris bawahi adalah dakwah secara sabar dan santun lebih dekat mencerminkan wajah Islam yang raḥmatan lil ālamīn jika dibanding dengan cara-cara yang radikal.

\section{Kesimpulan}

Kisah al-Qur'an sekali lagi memberikan sebuah pelajaran bahwa tanggung jawab adalah sebuah amanah 
sehingga harus diperlakukan dengan indah. Kisah nabi Yūnus merupakan demonstrasi adanya sebuah konsepsi sosial bahwa mengingkari tanggung jawab dapat berakibat fatal, namun tentu saja sebuah kesalah tetap dapat diperbaiki dengan adanya usaha dan pencapaian. Melalui metode hermeneutika Abdullah Saeed tulisan ini memunculkan kritik baru bahwa hermenutika Abdullah Saeed yang awalnya disiapkan untuk ayat ethico-legal, belakangan ini dapat digunakan sebagai interpretasi ayat kisah tentunya dengan beberapa penyesuaian dari empat metode menjadi tiga. Hasil dari pembahasan ini jelas bahwa Allah melarang adanya perbuatan ingkar tanggung jawab, larangan menyalah gunakan wewenang, dan menghimbau untuk selalu sabar dan santun dalam berdakwah di masyarakat. Beberapa saran untuk penelitian selanjutnya berkenan mengkaji beberapa hal yang sekiranya belum terulas dan tersentuh komprehensif terkait hermeneutika Abdullah Saeed, kesesuaian relasi antara ayat hukum dan ayat kisah sudahkah relevan atau belum, bahkan tentang hukuman yang setimpal bagi pelaku ingkar tanggung jawab. Kritik dari penulis dalam penelitian ini adalah besar harapan jika kelak terdapat peneliti yang kemudian berkenan mengkaji beberapa pembahasan tersebut. Wallahu a'lam.

\section{Referensi}

1. Afsar, Ayaz. "A Comparative Study Of The Art Of Jonah/Yūnus Narrative In The Bible And The Qur'ān," T.T., 22.

2. Al-Marāghi, Ahmad Muștafa. 1998. Tafsir Al-Marāghi. Beirut: Dār AlSya'ab

3. Arabi, Abu Bakar Ibn Al-. Ahkam AlQur'an. 2008. Libanon: Dār Al-Kutub Al-'Alamiyyah, Bruinessen,

4. Martin Van. Kitab Kuning, Pesantren, Dan Tarekat. 2015. Yogyakarta: Gading Publishing, 2015.

5. Daulay, Afrahul Fadhila. "Tanggung Jawab Pendidikan Islam,". 2017. Jurnal al-Irsyad. Vol. 7. No. 2.

6. Fina, Lien Iffah Naf'atu. 2015. "Interpretasi Kontekstual Abdullah Saeed: Sebuah Penyempurnaan Terhadap Gagasan Tafsir Fazlur Rahman." Dalam Jurnal Hermeneutik. Vol. 9, No. 1.

7. - - . $2011 . \quad$ “Interpretasi Kontekstual: Studi Pemikiran Hermeneutika Al-Qur'an Abdullah Saeed." Esensia: Jurnal Ilmu-Ilmu Ushuluddin. Vol. 12, No. 1.

8. Ibn 'Āsyūr, Muhammad Al-Ṭāhir. AlTahrì Wa Al-Tanwir. Tunisia: Dar AlTunisiyya, 1984.

9. Iskandar, Yimmy. 2019. "Makna Teologis Respon Nabi Yunus Terhadap Panggilan Tuhan." Jurnal Teologi Berita Hidup 2, No. 1.

10. Jābirī, 'Ābed Al-. 2006. Madkhal Ilā Al-Qur'ān Al-Karim: Al-Juz Al-Awwal Fì Ta'Rìf Bi Al-Qur'ān. Beirut: Markaz Dirāsat Al-Waḥdah Al'Arābiyyah

11. __ 'Ābed Al-. 2010. Kitab Fahm AlQur'ān Al-Hakim: Al-Tafsìr Al-Wādih Hasba Tartīb Al-Nuzūl. Beirut: Dār AlSyurūq.

12. Kafrāwīyy, As'ad 'Abd Al-Ghani AlSayyid Al-. 2009. .Istidlāl 'Inda 
Ușūliyyīn. Kairo: Dār Al-Kutub AlAlamiyyah,

13. Khallāf, Abd Wahhāb. 1968.'Ilm Ușūl Al-Fiqh. Kairo: Dār Al-Kutub Al'Alamiyyah,

14. Mahalli, Jalaluddin Al-, Dan Jalaluddin Al-Suyuti. 2017. Tafsir Jalālain. Beirut: Dār Al-Fikr Al-Islāmy.

15. Manẓur, Ibn. Lisānul Arab. 2008. Beirut: Dār Al-Kutub Al-'Alamiyyah.

16. Mustaqim, Abdul. 2011. "Kisah AlQur'an: Hakekat, Makna, Dan NilaiNilai Pendidikannya." Ulumuna. Vol. 15, No. 2.

17. Prabowo, Triyanto Setyo, Dan Mulyoto. 2017 “Tanggung Jawab Calon Notaris Yang Sedang Magang Terhadap Kerahasiaan Akta." Jurnal Repertorium. Vol. 4, No. 2.

18. Qațțān, Mannā' Al-. 1973. .Mabāhisis Fì 'Ulūm Al-Qur'an. Kairo: Dār Al-Kutub Al-'Alamiyyah,

19. Quthb, Sayyid. 2011Tafsir Fi Zhilalil Qur'an Di Bawah Naungan Al-Qur'an,. Jakarta: Gema Insani Press.

20. Rahman, Miftahur. 2017. “Uli Al-Amr Dalam Alquran: Sebuah Aplikasi Teori Kontekstual Abdullah Saeed." Jurnal Studi Ilmu-Ilmu Al-Qur'an Dan Hadis. Vol. 18, No. 2.

21. Razi, Al-Imam Al-Ālim Al-'Allamah Al-Habru Al-Bahru Al-Fahmah Fakhruddin Muhammad Ibn 'Umar Al-Tamīmī Al-. 1998. Mafātih Al-Ghaib. Beirut: Dār Al-Kutub Al-'Alamiyyah.

22. Ridwan, M. K. 2016. "Metodologi Penafsiran Kontekstual; Analisis Gagasan Dan Prinsip Kunci Penafsiran Kontekstual Abdullah Saeed." Millati: Journal Of Islamic Studies And Humanities. Vol. 1, No. 1

23. Saeed, Abdullah. 2006. Interpreting The Qur'an: Towards A Contemporary Approach. New York: Outledge.

24. - - . , 2018. Pengantar Studi AlQur'an. Yogyakarta: Baitul Hikmah Press.

25. Samsudin, Sahiron. 2019. “Pendekatan Dan Analisis Dalam Penelitian Teks
Tafsir:" Suhuf Jurnal Pengkajian AlQur'an Dan Budaya. Vol. 12. No. 1.

26. Sherwood, Yvonne. 2000. A Biblical Text And Its Afterlives: The Survival of Jonah In Western Culture. Cambridge University Press.

27. Siswayanti, Novita. 2010. “Dimensi Edukatif Pada Kisah-Kisah AlQur'an." Suhuf Jurnal Pengkajian AlQur'an Dan Budaya. Vol. 3. No. 1.

28. Sovia, Sheyla Nichlatus. 2016. "Interpretasi Kontekstual (Studi Pemikiran Hermeneutika Al-Qur'an Abdullah Saeed)." Dialogia: Jurnal Studi Islam Dan Sosial. Vol. 13. No. 1

29. Sucahyo, Nurhadi. "Aneh, Masyarakat Religius Namun Korupsi Tinggi." dalan Https:/ /Www.Voaindonesia.Com/A / Aneh-Masyarakat-Religius-NamunKorupsi-Tinggi/4587783.Html. Diakses 12 November 2019.

30. Sulaiman Haiṡamī, Abu Bakar Nuruddin 'Ali Ibn Abi Bakar. 1998. Mujma' Al-Zawāid. Beirut: Dar Ibn AlQayyim.

31. Sulaiman, Muqātil Ibn. 1998. Tafsìr Muqātil Ibn Sulaiman. Beirut: Dār AlFikr Al-Islāmy..

32. Tabarī, Abu Ja'far Muhammad Ibn Jarīr Al-. 2003. Jāmi' Al-Bayān Fi Tafsìr Al-Qur'ān. Beirut: Dār Al-Kutub Al'Alamiyyah.

33. Thalhah, Ali Bin Abi. 2009. Tafsir Ibnu Abbas. Jakarta: Pustaka Azzam.

34. "UU No.39 Thn 1999 - Hak Asasi Manusia (HAM)." dalam Http://Hukum.Unsrat.Ac.Id/Uu/Uu _39_99.Htm. Diakses 12 November 2019.

35. Wahyudi, Setya. 2011. “Tanggung Jawab Rumah Sakit Terhadap Kerugian Akibat Kelalaian Tenaga Kesehatan Dan Implikasinya." Jurnal Dinamika Hukum. Vol. 11, No. 3.

36. Zaenuddin, Mamat, dan Wagino Hamid Hamdani. 2015. "Formulasi Gaya Bahasa Ingkari Dalam Alquran." 
El-Afkar Vol. 9 Nomar. I, Januari-Juni 2020

Jurnal Pendidikan Bahasa Dan Sastra.

Vol. 15. No. 1. 